\title{
THE RNA EXPRESSION LEVEL OF SURVIVIN, OCT 4 AND CYCLIN D1 GENES IN TRIPLE NEGATIVE AND NON-TRIPLE NEGATIVE BREAST CANCER
}

\author{
Safaa Fawzy ${ }^{* 1}$, Karima Metwaly ${ }^{2}$, Mahmoud N. El-Rouby ${ }^{1}$, Abeer Bahnassy ${ }^{3}$ \\ ${ }^{1}$ Department of Cancer Biology, Virology and Immunology Unit, National Cancer \\ Institute, Cairo University, Egypt. \\ ${ }^{2}$ Department of parasitology Faculty of science, Al Azhar university (Girls branch) Cairo, \\ Egypt. \\ ${ }^{3}$ Molecular Pathology, National Cancer Institute, Cairo University, Egypt. \\ *Corresponding author: safaa.hafez.59@azhar.edu.eg
}

\begin{abstract}
Background: the purpose of the present study to investigate the RNA expression level of Oct4, Survivin and Cyclin D1 genes in Triple-negative breast cancer (TNBC) and compared to non-triple negative breast cancer (non-TNBC) group. Also, correlate the results of gene expression with clinicopathological features of patients. Method, RNA expression levels of Oct4, Survivin and Cyclin D1 was tested for 100 breast cancer (BC) patients [formalin fixed paraffin embedded tissue (FFPE)] diagnosed as invasive duct carcinoma in Pathology Department, National Cancer Institute (NCI), Cairo University. The qRT-PCR technique is use and the results correlated to clinico-pathological characteristics of patients and survival rates. Result, in (TNBC) patients, oct4, survivin and cyclin D1 showed positive expression in $30(60 \%), 32(64 \%)$ and $32(64 \%)(\mathbf{p}<\mathbf{0 . 0 0 1}, \mathbf{p}=$ $\mathbf{0 . 0 0 1}$ and $\mathbf{p}=\mathbf{0 . 0 0 3}$; respectively). In non-TNBC patients, the positive expression of oct4, survivin and cyclin DI gene was $11(22 \%), 15(30 \%)$ and $17(34 \%)(\mathbf{p}<\mathbf{0 . 0 0 1}, \mathbf{p}=\mathbf{0 . 0 0 1}$ and $\mathbf{p}=\mathbf{0 . 0 0 3}$; respectively). All patients in TNBC have negative $E R, P R$ and $H E R-2$ receptor $(\mathrm{p}=0.001)$. There was highly statistically significant difference between oct 4 gene expression and all the clinico-pathological features except the family history. A significant difference between cyclin Dlgene expression and all the clinico-pathological features except the tumor size, tumor grade and lymphnode status. Statistically difference was found between survivin gene expression and all the clinico-pathological features except the menopause state, tumor stage and tumor grade. Triple negative breast cancer patients showed significantly decreased DFS ( $\mathbf{p}<\mathbf{0 . 0 0 1}, \log$ rank) and OS $(\mathbf{p}=\mathbf{0 . 0 0 2}, \log$ rank) when compared to those with non-TNBC patients. In TNBC group, patients with positive expression of survivin was significantly associated with decreased OS (p=0.03, log rank). TNBC tumors with positive oct4 and cyclin DI had reduced OS compared to those negative to oct4 and cyclin D1 but without significant difference $(\mathbf{p}=\mathbf{0 . 8}$ and $\mathbf{p}=\mathbf{0 . 0 9}$, respectively, log rank). In non-TNBC group, with positive oct4, cyclin D1 and survivin did not significantly differ in terms of DFS and OS when compared to those with negative expression.

Conclusion: Oct4 and survivin expression gene are better marker used for diagnosis in TNBC and for molecular targeting therapy of TNBC treatment. Cyclin D1 expression used as a marker for aggressive TNBC. The TNBC tumor possibly respond to treatment that downregulates cyclin D1 amplifica tion. More studied and large sample size is needed.
\end{abstract}

Key words: Triple negative breast cancer, Oct4, CyclinD1, Survivin 


\section{Introduction}

Breast is a heterogenous disease composed of different molecular subtypes that differ in patterns of gene expression, clinical features, response to treatment, and prognosis Munjal $K$ et al., (2009) and Curtis $C$ et al., (2012). Triple negative breast cancer, characterized by lack of expression of $E R-\alpha, P g R$ and $H E R-2$, is its- self a heterogenous disease and accounts for $\sim 15 \%$ of all breast cancer cases. In Egypt, TNBC phenotype is highly prevalent compared to US and other Western countries Danielle Bogan et al., (2017) and El-Hawaryet al., (2012). Triple negative breast cancer (TNBC) tumors are responsive to a wide range of chemotherapeutic agents, majority of patients are more likely to develop recurrence during the first three years after treatment Kaplan, H.G. et al., (2009) with predominance of visceral and central nervous system metastases Liedtke, C.et al., (2008). TNBC is essential, there are incomplete overlap in immunohistochemistry determine it, molecular analysis to basal-like breast cancer and the mutation of BRCA1 that correlated with breast cancer. In this study, they reported that about $80 \%$ of TNBC have a basal-like molecular profile Weigelt et al., (2010a).

The octamer-binding transcription factor 4 (oct4) is a transcription factor known as POU (Pituitary-specific Pit-1, Octamer transcription factor, and neural Unc-86 transcription factor) domain class 5 Homeobox transcription factor 1 (POU5F1). It regulates the pluripotency of pluripotent stem cells. The POU5F1 gene is located on chromosome 6p21.33 (Liu et al., 2013). The expression of oct4 is high in the most types of cancer cells either solid or hematological. Otherwise, the downregulated of oct 4 inhibits cell proliferation or metastasis in different types. of tumors. The oct 4 overexpression was suppressed the metastasis in breast cancer cells (Shen et al., 2014). Thus, the reprogramming factor oct4 may regulate cancer properties differentially.

Cyclins consisted of about 30 proteins with weight from 35 to $90 \mathrm{kDa}$. The structures of cyclins proteins determined by cyclin box which contains approximately one hundred domain amino acid residues that forms a stack of five $\alpha$-helices. Cyclins regulates the activity of cyclin-dependent kinases $(C d k s)$, so they can control the progression of cell cycle.(Malumbres and Barbacid, 2005). The cyclin-CDK complexes rule a linear progression of events that change the cells from a resting state $(\mathrm{G} 0)$ to the growth phase $(\mathrm{G}$ 1), through DNA replication (S)in the $S$ phase followed by cell division (M). (Sarosiek, 2018). Cyclin D1 is an oncogene that is directly related to the carcinogenesis. cyclin Dl gene was high expression many cancers. It was expressed in about $50 \%$ in invasive breast cancer patients compared to normal epithelium. Its amplification rate is approximately $13 \%$ of the normal epithelium (Choi et al., 2018).

Cancer cell proliferation affected by survivin overexpression. It inhibits apoptosis protein family that inhibits caspases then stoop cell death. It has a poor outcome survival of patients. Survivin expression was correlated significantly with high tumor grade, survival rates and recurrence. Survivin gene polymorphisms can help to understand the biology of the disease. It is a prognostic and predictive factor ( $\mathbf{L i}$ et al., 2017b and Boullosa et al., 2018). 


\section{Methods}

\section{Patients and tissues specimens}

Tissues specimens (Formalin-fixed paraffin-embedded (FFPE) tissue blocks) for 100 patients who were diagnosed as invasive duct carcinoma. All patients attended in the National Cancer Institute (NCI), Cairo University. All patients have the relevant clinicopathological and follow up data. All cases were diagnosed as stage and grade according to the WHO (Fletcher CDM BJ et al., 2013). Fifty FFPE tissue blocks of breast cancer patients who had negative estrogen $(E R)$, progesterone $(P R)$ and Her/2 neu receptors (TNBC). And another fifty samples who have the positive ER, PR and Her/2 neu receptors (non-TNBC). Twenty tissues block of normal tissue as a control group. The representative paraffin blocks, $5 \mu \mathrm{m}$ thick sections ( 7 sections) were cut into a sterile, plastic, $2 \mathrm{ml}$ Eppindorff tube for RNA extraction and quantitative real time polymerase chain reaction (qPCR).

\section{The extraction of RNA}

The RNA was extracted from the tumor as well as the normal tissues using the RNeasy Mini Kit (Qiagen, Milan, Italy) and by spectrophotometry the quality of RNA was estimated. Dissolve RNA in diethyl pyrocarbonate-treated water containing $10 \mathrm{mmol} / \mathrm{l}$ of $\mathrm{MgCl}$.Incubation for $30 \mathrm{~min}$ at $37^{\circ} \mathrm{C}$ with $100 \mu \mathrm{g} / \mathrm{ml}$ of RNase-free DNaseI to remove the contaminating DNA. Add EDTA to a final concentration of $30 \mathrm{mmol} / \mathrm{l}$, the reaction was stopped at $95{ }^{\circ} \mathrm{C}$ for 5. RNA was retro transcribed using iScriptTM cDNA Synthesis Kit (Bio-Rad, Milano, Italy). The qRT-PCR analysis was performed in a final volume of $25 \mu 1$ with a SYBR Green PCR Master Mix using $1 \mu \mathrm{l}$ cDNA and $400 \mathrm{nM}$ of predesigned.

Amplification of Oct4, Cyclin D1, Survivin and $\beta$-actin mRNA in the samples were assessed in triplicates using the primers

1) Oct4 Forward: 5'-GATGGCGTACTGTGGGCCC-3'

Reverse: 5'-TGGGACTCCTCCGGGTTTTG-3'

2) Cyclin D1 Forward: 5'-CTGGGTGTCCTACAAATG-3'

Reverse: 5'-AGCGGTCCAGGT AGTTCAT-3'

3) Survivin Forward: 5'-TCCACTGCCCCACTGAGAAC-3'

Reverse: 5'-TGGCTCCCAGCCTTCCA-3'

4) $\beta$-actin Forward: 5'-ACAGAGCCTCGCCTTTGC-3'

Reverse: 5'- GCGGCGATATCATCATCC-3' 


\section{Interpretation of the $\mathrm{qPCR}$ results}

Calculate the mean cycle threshold (CT value) to 1- determine the delta $\mathrm{CT}(\Delta \mathrm{CT})$ for each sample as follows: $\Delta \mathrm{CT}=\mathrm{CT}$ for the gene of interest-CT of the internal control gene ( $\beta$-actin). 2 - the delta delta $\mathrm{CT}(\Delta \Delta \mathrm{CT})$ was calculated as follows: $\Delta \Delta \mathrm{CT}=(\Delta \mathrm{CT}$ for sample A - $\Delta$ CT for sample B), where sample A is the tumor and sample B is the calibrator (normal breast). For the statistical analysis, the $\Delta \Delta \mathrm{CT}$ was used and then the data were expressed as relative expression units Schmittgen TD and Livak KJ. (2008).

\section{Statistical method:}

Mann-Whitney test (non-parametric t-test) method was used to comparison the quantitative data between TNBC ana non-TNBC group. Kaplan-Meier method, and the log-rank test was done to calculate the survival functions and to compare the survival curves. Cox proportional hazards model analyze the prognostic factors of disease-free survival and overall survival. The hazard ratios (HRs) were calculated with a 95\% confidence interval (CI). All tests were two-tailed. The $\mathrm{p}$ value, $p<0.05$, was considered significant.

\section{Results}

The study involved hundred breast cancer patients diagnosed as invasive duct carcinoma of the breast. The patients were divided into two groups (TNBC and nonTNBC). The relation of the studied markers (Oct4, Cyclin D1 and Survivin) and the two groups was assessed. The results were correlated with the relevant clinic-pathological features of patients as well as to demonstrate the response to treatment and outcome of patients.

\section{- Clinico-pathological patient's characteristics}

The features of all breast cancer patients (100 patients) demonstrated in Table 1, all patients had negative estrogen (ER), progesterone (PR) and Her-2/neu receptors. There were not statistically significant difference of the relevant clinico-pathological features of patients and age, Tumor size and Menopausal status. The age $\leq 50$ year was in $54 \%$ and age $>50$ year was in $64 \%(\mathrm{p}=0.554)$. The tumor size was detected in $48 \%$ with the diameter $\leq 5 \mathrm{~cm}$ versus to $52 \%$ with tumor size $>5 \mathrm{~cm}(\mathrm{p}=770)$. Moreover, $54 \%$ of patients had postmenopausal status versus to $46 \%$ of patients had premenopausal status $(\mathrm{p}=0.334)$. There was a significant association between clinico-pathological features of patients and the lymph node status, tumor grade, family history, stage, margin and chemotherapy treatment. Family history was found in $11 \%$ of all patient and absent in $89 \%$ of patients $(\mathrm{p}=0.001)$. The patients which had grade I-II were in $81 \%$ of patients compared to $19 \%$ with grade III-IV( $p=0.017)$. Regrade to tumor stage, $80 \%$ of patients were in early stage and $20 \%$ with late stage of tumor $(\mathrm{p}=0.01)$. Lymphnode status, positive lymphnode was in $73 \%$ of patients and negative lymphnode was in $27 \%(\mathrm{p}=0.01)$. There was $93 \%$ of patients 
had free margin from tumor and $7 \%$ of patients had positive margin $(\mathrm{p}=0.001)$. Finally, $91 \%$ of patients were responded to the treatment versus $9 \%$ were non responder $(\mathrm{p}=0.001)$.

Table 1: Clinico-pathological feature of patients

\begin{tabular}{|c|c|c|}
\hline $\begin{array}{c}\text { Patient's } \\
\text { characteristics }\end{array}$ & $\begin{array}{c}\text { Frequency } \\
(\%)\end{array}$ & $P$ value \\
\hline $\begin{array}{l}\text { Age } \\
\leq 50 \\
>50\end{array}$ & $\begin{array}{l}54 \% \\
46 \%\end{array}$ & 0.554 \\
\hline $\begin{array}{l}\text { Tumor size } \\
\leq 5 \\
>5 \\
\end{array}$ & $\begin{array}{l}48 \% \\
52 \% \\
\end{array}$ & 0.770 \\
\hline $\begin{array}{l}\text { Family history } \\
\text { Negative } \\
\text { Positive } \\
\end{array}$ & $\begin{array}{l}89 \% \\
11 \% \\
\end{array}$ & 0.001 \\
\hline $\begin{array}{l}\text { Menopausal status } \\
\text { Post } \\
\text { Pre } \\
\end{array}$ & $\begin{array}{l}54 \% \\
46 \% \\
\end{array}$ & 0.334 \\
\hline $\begin{array}{l}\text { Grade } \\
\quad \text { I-II } \\
\text { III-IV } \\
\end{array}$ & $\begin{array}{l}81 \% \\
19 \% \\
\end{array}$ & 0.017 \\
\hline $\begin{array}{l}\text { Stage } \\
\text { Early } \\
\text { Late }\end{array}$ & $\begin{array}{l}80 \% \\
20 \%\end{array}$ & 0.01 \\
\hline $\begin{array}{l}\text { Lymph node } \\
\text { Negative } \\
\text { Positive } \\
\end{array}$ & $\begin{array}{l}27 \% \\
73 \%\end{array}$ & 0.01 \\
\hline $\begin{array}{l}\text { Margin } \\
\text { Free } \\
\text { Positive } \\
\end{array}$ & $\begin{array}{c}93 \% \\
7 \% \\
\end{array}$ & 0.001 \\
\hline $\begin{array}{l}\text { ER, PR and } \\
\text { Her2/new } \\
\text { Negative } \\
\text { Positive }\end{array}$ & $\begin{array}{c}100 \% \\
0 \%\end{array}$ & \\
\hline $\begin{array}{l}\text { Chemotherapy } \\
\text { No } \\
\text { Yes }\end{array}$ & $\begin{array}{l}9 \% \\
91 \%\end{array}$ & 0.001 \\
\hline
\end{tabular}

$E R$ : estrogen receptor; PR: progesterone receptor and HER2: human epidermal growth factor receptor 


\section{- Clinico-pathological features of TNBC and non-TNBC patients.}

TNBC patients have negative $E R, P R$ and $H E R-2$ receptor $(\mathrm{p}=0.001)$. At tumor size, 48 patients had tumor size $\leq 5 \mathrm{~cm}$ [25(52.1\%) in TNBC vs $23(47.9 \%)$ in non-TNBC] and fifty-two patients had tumor size $>5 \mathrm{~cm}$ [25(48.1\%) in TNBC vs $27(51.9 \%)$ in nonTNBC]. There was not Statistically difference between the tumor size in TNBC or nonTNBC group. $(\mathrm{p}=0.69)$ (Table2). The early stage (I\&II) was common in TNBC group than those in non-TNBC group, in TNBC 50 (62.5\%) vs 30 (37.5\%) were in non-TNBC. As for in stage III \& IV, 0/20(0 \%) were in TNBC compared to 20/20 (100\%) nonTNBC cases $(\mathrm{p}=0.0001)$. Stage (III-IV) was more significant in non-TNBC than those in TNBC (Table2). Grade I was found in 3 patients [2(66.7\%)] were in the TNBC group and only one $(33.3 \%)$ was in non-TNBC, seventy-eight patients had the tumor grade II [43(55.1\%) in TNBC compared to 35(44.9\%) in non-TNBC]. Finally, grade III reported in 19 cases [5(26.3\%) in TNBC and $14(73.7 \%)$ in non-TNBC] $(p=0.12)$ (Table2). In TNBC group, the mean \pm SD of the age was $51.2 \pm 12.5$ years old, in the TNBC 22 out of 46 were <50year-old vs. $28 / 54$ were $\geq 50$ year-old. In the non-TNBC, the mean \pm SD for the age is $53.3 \pm 12.3$ years old " 24 out of the 46 were less than 50 year-old compared to $18 / 54$ with more than 50year-old $(\mathrm{p}=0.68)$ (Table2). In premenopause, 23/46(50\%) were in TNBC group vs $23 / 46(50 \%)$ in non-TNBC one. In postmenopause $27 / 54(50 \%)$ were in TNBC group compared to $27 / 54(50 \%)(\mathrm{p}=0.33)$ (Table2). A higher proportion of patients had positive family history. Eleven patients have a family history, 10/11(90.9\%) in TNBC group and 1/11(9.1\%) in non-TNBC ( $\mathrm{p}=0.05)$ (Table2). Lymph node, $43(58.9 \%)$ out of the 73 patients were positive in the TNBC compared to $30(41.1 \%)$ cases in non-TNBC. In TNBC, the negative lymph node was in $7(25.9 \%)$ vs $20(74.1 \%)$ in non-TNBC cases $(\mathrm{p}=0.003)$ (Table 2). As for surgical margin, it was positive in $7(100 \%)$ patients in TNBC patients but none in the non-TNBC patients $(\mathrm{p}=0.014)$ (Table 2). Response to treatment given good outcome in non-TNBC [35/55(63.6\%)] than those in TNBC [20/55 (36.4\%)]. Whereas 45 patients did not respond to treatment [ 33(73.3\%) in TNBC and 12(26.7\%) in non-TNBC group. A significantly higher proportion of patients in the non-TNBC group responded to the given treatment (chemotherapy and/or radiotherapy) compared to the TNBC patients (35 verses 20 patients: respectively $(\mathrm{p}=0.001)$ (Table2). 
Table 2: The clinico-pathological features of TNBC and non-TNBC patients

\begin{tabular}{|c|c|c|c|}
\hline Parameters & $\begin{array}{l}\text { TNBC } \\
\text { N }(\%) \\
\end{array}$ & $\begin{array}{c}\text { non-TNBC } \\
\mathbf{N}(\%)\end{array}$ & P value \\
\hline $\begin{aligned} \text { Age }(\mathbf{y r}): & <50(\mathrm{n}=46) \\
& \geq 50(\mathrm{n}=54)\end{aligned}$ & $\begin{array}{l}22 / 46) \\
(28 / 54)\end{array}$ & $\begin{array}{l}(24 / 46) \\
(26 / 54)\end{array}$ & 0.68 \\
\hline $\begin{array}{r}\text { Menopause: Pre }(\mathrm{n}=46) \\
\text { Post }(\mathrm{n}=54)\end{array}$ & $\begin{array}{l}(23 / 46) \\
(27 / 54)\end{array}$ & $\begin{array}{l}(23 / 46) \\
(27 / 54)\end{array}$ & 0.33 \\
\hline $\begin{array}{l}\text { Family History } \\
\text { Absent }(n=89) \\
\text { Present }(n=11)\end{array}$ & $\begin{array}{l}(40 / 89) \\
(10 / 11)\end{array}$ & $\begin{array}{c}(49 / 89) \\
(1 / 11) \\
\end{array}$ & 0.05 \\
\hline $\begin{array}{l}\text { Tumor size }(\mathbf{c m}): \\
\leq 5(n=48) \\
>5(n=52)\end{array}$ & $\begin{array}{l}(25 / 48) \\
(25 / 52)\end{array}$ & $\begin{array}{l}(23 / 48) \\
(27 / 52)\end{array}$ & 0.69 \\
\hline $\begin{array}{l}\text { Tumor stage: } \\
\text { Low (0-I) }(\mathrm{n}=21) \\
\text { Early (II) }(\mathrm{n}=59) \\
\text { Late (III) }(\mathrm{n}=20) \\
\end{array}$ & $\begin{array}{c}(21 / 21) \\
(29 / 59) \\
(0 / 20) \\
\end{array}$ & $\begin{array}{l}(0 / 21) \\
(30 / 59) \\
(20 / 20) \\
\end{array}$ & 0.0001 \\
\hline $\begin{array}{l}\text { Tumor Grade: } \\
1(n=3) \\
2(n=78) \\
3(n=19)\end{array}$ & $\begin{array}{c}(2 / 3) \\
(43 / 78) \\
(5 / 19) \\
\end{array}$ & $\begin{array}{c}(1 / 3) \\
(35 / 78) \\
(14 / 19)\end{array}$ & 0.12 \\
\hline $\begin{array}{l}\text { LN status: } \\
\text { Positive }(n=73) \\
\text { Negative }(n=27)\end{array}$ & $\begin{array}{c}(43 / 73) \\
(7 / 27)\end{array}$ & $\begin{array}{l}(30 / 73) \\
(20 / 27)\end{array}$ & 0.003 \\
\hline $\begin{array}{l}\text { Margin } \\
\quad \text { Free }(n=93) \\
\text { Positive }(n=7)\end{array}$ & $\begin{array}{c}(43 / 93) \\
(7 / 7)\end{array}$ & $\begin{array}{l}(50 / 93) \\
0(0.0 \%)\end{array}$ & 0.014 \\
\hline $\begin{array}{c}\text { Chemotherapy } \\
\text { Yes }(\mathrm{n}=91) \\
\text { No }(9)\end{array}$ & $\begin{array}{c}(48 / 91) \\
(2 / 9)\end{array}$ & $\begin{array}{l}(43 / 91) \\
(7 / 9)\end{array}$ & 0.160 \\
\hline $\begin{array}{l}\text { Ungrouped Response } \\
\text { Yes (55) } \\
\text { No (45) } \\
\end{array}$ & $\begin{array}{l}(20 / 55) \\
(33 / 45)\end{array}$ & $\begin{array}{l}(35 / 55) \\
(12 / 45) \\
\end{array}$ & 0.001 \\
\hline $\begin{array}{l}\boldsymbol{E R} \\
\quad \text { Positive (37) } \\
\quad \text { Negative (63) } \\
\end{array}$ & $\begin{array}{l}(0 / 37) \\
(50 / 63)\end{array}$ & $\begin{array}{l}(37 / 37) \\
(13 / 63) \\
\end{array}$ & 0.001 \\
\hline $\begin{array}{l}P \boldsymbol{R} \\
\quad \text { Positive (29) } \\
\quad \text { Negative (71) }\end{array}$ & $\begin{array}{l}(0 / 29) \\
(50 / 71)\end{array}$ & $\begin{array}{l}(29 / 29) \\
(21 / 71) \\
\end{array}$ & 0.001 \\
\hline $\begin{array}{l}\text { HER-2 } \\
\quad \text { Positive (18) } \\
\quad \text { Negative (82) } \\
\end{array}$ & $\begin{array}{c}(0 / 18) \\
(50 / 82)\end{array}$ & $\begin{array}{l}(18 / 18) \\
(32 / 18)\end{array}$ & 0.001 \\
\hline
\end{tabular}

LN: lymph node; ER: estrogen receptor; PR: progesterone receptor and HER2: human epidermal growth factor receptor 
- mRNA expression levels of Oct4, Survivin and Cyclin D1 genes in the two groups (TNBC and non-TNBC).

There was significant association between RNA expression level of oct4, survivin and cyclin D1 genes and TNBC or non-TNBC group $(\mathrm{p}<0.001, \mathrm{p}=0.001$ and $\mathrm{p}=0.003$; respectively). RNA expression level of oct4, survivin and cyclin D1 was $60 \%, 32 \%$ and $32 \%$; respectively in TNBC patients. In non-TNBC patients, RNA expression level of oct4, survivin and cyclin Dl genes was $22 \%, 15 \%$ and $17 \%$ of patients (Table 3 ).

Table 3. RNA expression level of oct4, survivin and cyclin D1 in TNBC and nonTNBC patients

\begin{tabular}{|l|c|c|c|}
\hline \multicolumn{1}{|c|}{ Gene marker } & $\begin{array}{c}\text { TNBC } \\
\mathrm{n}=50\end{array}$ & $\begin{array}{c}\text { non-TNBC } \\
\mathrm{n}=50\end{array}$ & P value \\
& $(\%)$ & $(\%)$ & \\
\hline Oct4 & $30(60 \%)$ & $11(22 \%)$ & $<0.0001$ \\
High & $20(40 \%)$ & $39(78 \%)$ & \\
Low & $32(64 \%)$ & $15(30 \%)$ & 0.001 \\
\hline Survivin & $18(36 \%)$ & $35(70 \%)$ & \\
High & $32(64 \%)$ & $17(34 \%)$ & 0.003 \\
Low & $18(36 \%)$ & $33(66 \%)$ & \\
\hline Cyclin D1 & & & \\
High & & & \\
Low & & & \\
\hline
\end{tabular}

TNBC:Triple negative breast cancer, non-TNBC:Non Triple negative breast cancer, Oct4:biomarker gene, Survivin: biomarker gene, CyclinD1: biomarker gene

\section{- Correlation between Oct4, Cyclin D1 and Survivin gene expression and patient's} feature in TNBC

In the TNBC group. The oct 4 gene, the mean fold expression was 2.0 -fold with the age $<50$ year and 2.7 fold with the age $\geq 50$ year, $(p=0.03)$. In premenopause status, the mean fold expression was 2.3 -fold vs 2.5 fold in postmenopause, $(\mathrm{p}=0.031)$. The mean fold expression was 1.44 -fold in tumor size $\leq 5 \mathrm{~cm}$ compare to 1.0 fold in tumor size $>5 \mathrm{~cm}$, $(\mathrm{p}=0.01)$. The mean fold expression was 2.4 fold in the early tumor stage compared to 2.6fold in late tumor stage, $(\mathrm{p}=\mathrm{o} .03)$. The mean fold expression was 2.7 fold with tumor grade (I, II) compared to 1.7 fold in tumor grade (III), $(\mathrm{p}=0.02)$. Similarly, the mean fold expression was 2.3 -fold with positive lymphnode vs 3.0 fold in negative cases, $(\mathrm{p}=0.01)$. 
Finally, the mean fold expression was 2.8 fold in metastasis state compared to 1.6 fold in non- metastatic state, $(\mathrm{p}=0.003)$ (Table4). There was a high significant difference between the expression of oct 4 and the clinic-pathological features except the family history.

The mean fold expression of cyclin DI gene was 4.3 fold with the age of patients $<50$ year and 3.5 fold with age $\geq 50$ year $(\mathrm{p}=0.02)$. In premenopause status, the mean fold expression was 3.8 fold compared to 4.0 fold in postmenopause $(\mathrm{p}=0.01)$. The mean fold expression was 3.9 fold in cases who have no family history compared to 0.33 fold in cases who have family history, $(\mathrm{p}=0.001)$. The mean fold expression was 3.7 fold in the early tumor stage compared to 4.3 fold expression in late tumor stage, $(\mathrm{p}=\mathrm{o} .03)$. Finally, in metastatic status, the mean fold expression was 4.3 fold in metastasis state compared to 2.9 fold in no metastatic state, $(\mathrm{p}=0.003)$ (Table4). There was a significant difference between cyclin Dl expression and age, menopause, family history, tumor stage and metastasis status.

The data detected that the mean fold expression of survivin gene was 2.8 fold in age $<50$ year and 3.7 fold in age $\geq 50$ year, $(\mathrm{p}=0.001)$. the mean fold expression was 3.3 fold with the patients who have no family history compared to 0.32 fold in the patients who have family history, $(\mathrm{p}=0.002)$. Similarly, in tumor size $\leq 5 \mathrm{~cm}$, the mean fold expression was 2.5 fold and 2.8 fold with size $>5 \mathrm{~cm},(\mathrm{p}=0.01)$. In negative lymphnode status the mean fold expression was 2.7 fold compared to 3.4 fold in positive lymphnode, $(\mathrm{p}=0.04)$. The mean fold expression was 2.4 fold in patients who have no metastatic status compared to 3.7 fold in in metastatic status, $(\mathrm{p}=0.03)$ (Table 4). There was statistically difference between survivin and age, family history, tumor size, lymphnode and metastatic status.

\section{- The relation between Oct4, Cyclin D1 and Survivin gene expression and patient's features in non-TNBC}

In the non-TNBC group, a highly significant association was found between oct 4 gene expression and family history, tumor size, tumor grade and metastasis. The mean fold expression was 1.0 fold in patients who have no family history compared to 1.44 fold in patients who have family history $(\mathrm{p}=0.05)$. The mean fold expression levels were 1.4 fold with the tumor size $\leq 5 \mathrm{~cm}$ and 0.89 fold in tumor size $>5 \mathrm{~cm}$, ( $\mathrm{p}=0.002$ ). Regard to tumor grade, the mean fold expression was 1.0fold in grade I, II compared to 1.9fold in grade III, (p0.003). Finally, the mean fold expression was 1.0fold in the patients who have no metastasis compared to 1.4 fold in the patients who have metastasis status, $(\mathrm{p}=0.02)$ (Table $5)$.

There was a significant association between cyclin Dlgene expression and tumor size, tumor grade and lymphnode. The mean fold expression was 3.2 fold with the tumor size $\leq 5 \mathrm{~cm}$ and 2.6fold in tumor size $>5 \mathrm{~cm},(\mathrm{p}=0.05)$. As for tumor grade, the mean fold expression was 2.7 fold in grade I, II compared to 2.3 fold in grade III, $(\mathrm{p}=0.02)$. And the mean fold expression was 2.3 fold in negative lymphnode compared to 3.2 fold in positive one, $(\mathrm{p}=0.002)$ (Table 5). 
The mean fold expression of survivin gene was 2.9 fold with the age<50year compared to 1.09 fold with the age $\geq 50$ year, $(\mathrm{p}=0.03)$. The mean fold expression was 2.7 fold in absence of family history vs 2.28 fold with the patients who have family history, $(\mathrm{p}=0.03)$. At tumor size $\leq 5 \mathrm{~cm}$, the mean fold expression was 2.49 fold and 2.82 fold in the tumor size $>5 \mathrm{~cm},(\mathrm{p}=0.4)$. As for, the mean fold expression was 2.8 fold for early stage of tumor compared to 2.4flod for late tumor stage, $(\mathrm{p}=0.002)$ (Table 4). With the tumor grade (I, II), the mean fold expression was 2.69fold while in cases with tumor grade (III, IV) the mean fold expression was 2.31 fold, $(\mathrm{p}=0.04)$. Finally, with positive lymphnode, the mean fold expression was 2.2 fold and it was 2.96 fold with negative lymphnode cases, $(\mathrm{p}=0.04)$ (Table5). There was a significant correlation between the survivin gene expression and all clinic-pathological characteristic of patients except the menopause and metastasis 
Table 4: The association between Oct, Cyclin D1 and Survivin genes mRNA-expression levels with the clinico-pathological features in TNBC patients

\begin{tabular}{|c|c|c|c|c|c|c|c|c|c|c|c|c|}
\hline \multirow[t]{2}{*}{ Parameters } & \multicolumn{2}{|c|}{ Oct Exp. } & \multirow{2}{*}{$\begin{array}{c}\text { Oct } 4 \\
\text { Mean fold } \\
\text { expression }\end{array}$} & \multirow{2}{*}{$\begin{array}{c}P \\
\text { value }\end{array}$} & \multicolumn{2}{|c|}{ Cyclin D1Exp. } & \multirow{2}{*}{$\begin{array}{l}\text { Cyclin D1 } \\
\text { Mean fold } \\
\text { expression }\end{array}$} & \multirow[t]{2}{*}{ P value } & \multicolumn{2}{|c|}{ Survinin Exp. } & \multirow{2}{*}{$\begin{array}{c}\text { Survinin } \\
\text { Mean fold } \\
\text { expression }\end{array}$} & \multirow[t]{2}{*}{ P value } \\
\hline & High & Low & & & High & Low & & & High & Low & & \\
\hline $\begin{array}{l}\text { Age }(\mathbf{y r}): \\
<50(n=24) \\
\geq 50(n=26)\end{array}$ & $\begin{array}{l}15 \\
17 \\
\end{array}$ & $\begin{array}{l}9 \\
9 \\
\end{array}$ & $\begin{array}{l}2.0 \pm 1.4 \\
2.7 \pm 2.1 \\
\end{array}$ & 0.03 & $\begin{array}{l}20 \\
19 \\
\end{array}$ & $\begin{array}{l}4 \\
7 \\
\end{array}$ & $\begin{array}{c}4.3 \pm 2 \\
3.5 \pm 2.1\end{array}$ & 0.02 & $\begin{array}{l}16 \\
22 \\
\end{array}$ & $\begin{array}{l}8 \\
4 \\
\end{array}$ & $\begin{array}{c}2.8 \pm 2 \\
3.7 \pm 1.9\end{array}$ & 0.001 \\
\hline $\begin{array}{l}\text { Menopause: } \\
\text { Pre }(n=23) \\
\text { Post }(n=27)\end{array}$ & $\begin{array}{l}16 \\
16\end{array}$ & $\begin{array}{c}7 \\
11\end{array}$ & $\begin{array}{c}2.3 \pm 1.5 \\
2.5 \pm 2\end{array}$ & 0.031 & $\begin{array}{l}17 \\
22\end{array}$ & $\begin{array}{l}6 \\
5\end{array}$ & $\begin{array}{l}3.8 \pm 2.3 \\
4.0 \pm 1.9\end{array}$ & 0.01 & $\begin{array}{l}19 \\
19\end{array}$ & $\begin{array}{l}4 \\
8\end{array}$ & $\begin{array}{l}3.5 \pm 1.9 \\
3.0 \pm 2.1\end{array}$ & 0.62 \\
\hline $\begin{array}{l}\text { Family History } \\
\text { Absent }(n=49) \\
\text { Present }(n=1)\end{array}$ & $\begin{array}{c}32 \\
0\end{array}$ & $\begin{array}{c}17 \\
1\end{array}$ & $\begin{array}{c}2.45 \pm 1.85 \\
0.35 \pm 00\end{array}$ & 0.062 & $\begin{array}{c}39 \\
0\end{array}$ & $\begin{array}{c}10 \\
1\end{array}$ & $\begin{array}{c}3.9 \pm 2 \\
0.33 \pm 00\end{array}$ & 0.001 & $\begin{array}{c}38 \\
0\end{array}$ & $\begin{array}{c}11 \\
1\end{array}$ & $\begin{array}{c}3.3 \pm 2 \\
0.32 \pm 00\end{array}$ & 0.002 \\
\hline $\begin{array}{l}\text { Tumor size (cm) } \\
\leq 5(\mathrm{n}=23) \\
>5(\mathrm{n}=27)\end{array}$ & $\begin{array}{l}13 \\
19 \\
\end{array}$ & $\begin{array}{c}10 \\
8 \\
\end{array}$ & $\begin{array}{c}1.44 \pm 1.2 \\
1.0 \pm 1.1\end{array}$ & 0.01 & $\begin{array}{l}15 \\
24 \\
\end{array}$ & $\begin{array}{l}8 \\
3 \\
\end{array}$ & $\begin{array}{l}3.2 \pm 1.9 \\
2.5 \pm 1.6\end{array}$ & 0.06 & $\begin{array}{l}16 \\
22 \\
\end{array}$ & $\begin{array}{l}7 \\
5 \\
\end{array}$ & $\begin{array}{l}2.5 \pm 1.8 \\
2.8 \pm 1.8\end{array}$ & 0.01 \\
\hline $\begin{array}{l}\text { Tumor stage } \\
\text { Early }(\mathrm{n}=30) \\
\text { Late }(\mathrm{n}=20)\end{array}$ & $\begin{array}{l}22 \\
17 \\
\end{array}$ & $\begin{array}{l}8 \\
3 \\
\end{array}$ & $\begin{array}{l}2.4 \pm 1.6 \\
2.6 \pm 2.1 \\
\end{array}$ & 0.03 & $\begin{array}{l}22 \\
17 \\
\end{array}$ & $\begin{array}{l}8 \\
3 \\
\end{array}$ & $\begin{array}{l}3.7 \pm 2.1 \\
4.3 \pm 2.0 \\
\end{array}$ & 0.03 & $\begin{array}{l}22 \\
16 \\
\end{array}$ & $\begin{array}{l}8 \\
4 \\
\end{array}$ & $\begin{array}{l}3.2 \pm 1.8 \\
3.5 \pm 2.2 \\
\end{array}$ & 0.13 \\
\hline $\begin{array}{l}\text { Tumor Grade } \\
\operatorname{I-II}(n=36) \\
\operatorname{III}(n=14)\end{array}$ & $\begin{array}{c}25 \\
7\end{array}$ & $\begin{array}{c}11 \\
7\end{array}$ & $\begin{array}{l}2.7 \pm 1.9 \\
1.7 \pm 1.4\end{array}$ & 0.02 & $\begin{array}{l}29 \\
10\end{array}$ & $\begin{array}{l}7 \\
4\end{array}$ & $\begin{array}{c}4 \pm 2.1 \\
3.5 \pm 2.2\end{array}$ & 0.07 & $\begin{array}{l}27 \\
11\end{array}$ & $\begin{array}{l}9 \\
3\end{array}$ & $\begin{array}{l}3.0 \pm 1.9 \\
3.8 \pm 2.2\end{array}$ & 0.25 \\
\hline $\begin{array}{l}\text { LN status: } \\
\text { Negative }(n=7) \\
\text { Positive }(n=43) \\
\end{array}$ & $\begin{array}{c}4 \\
28 \\
\end{array}$ & $\begin{array}{c}3 \\
15 \\
\end{array}$ & $\begin{array}{c}3.0 \pm 3 \\
2.3 \pm 1.6\end{array}$ & 0.01 & $\begin{array}{c}5 \\
34 \\
\end{array}$ & $\begin{array}{l}2 \\
9 \\
\end{array}$ & $\begin{array}{l}3.8 \pm 2.5 \\
3.9 \pm 2.0 \\
\end{array}$ & 0.31 & $\begin{array}{c}5 \\
33 \\
\end{array}$ & $\begin{array}{c}2 \\
10 \\
\end{array}$ & $\begin{array}{l}2.7 \pm 1.9 \\
3.4 \pm 2.0 \\
\end{array}$ & 0.04 \\
\hline $\begin{array}{l}\text { Metastasis: } \\
\text { M0 }(n=16) \\
\text { M1 }(n=34)\end{array}$ & $\begin{array}{c}7 \\
25 \\
\end{array}$ & $\begin{array}{l}9 \\
9 \\
\end{array}$ & $\begin{array}{l}1.6 \pm 1.4 \\
2.8 \pm 1.9\end{array}$ & 0.003 & $\begin{array}{c}9 \\
30\end{array}$ & $\begin{array}{l}7 \\
4 \\
\end{array}$ & $\begin{array}{l}2.9 \pm 2.4 \\
4.3 \pm 1.8\end{array}$ & 0.003 & $\begin{array}{c}8 \\
30 \\
\end{array}$ & $\begin{array}{l}8 \\
4 \\
\end{array}$ & $\begin{array}{c}2.4 \pm 2.2 \\
3.7 \pm 1.7)\end{array}$ & 0.03 \\
\hline
\end{tabular}


Table 5: The association between $O C T, C y c l i n$ D1 and Survivin genes mRNA-expression levels with the clinico-pathological features in non-TNBC patients

\begin{tabular}{|c|c|c|c|c|c|c|c|c|c|c|c|c|}
\hline \multirow[t]{2}{*}{ Parameters } & \multicolumn{2}{|c|}{ Oct Exp. } & \multirow{2}{*}{$\begin{array}{c}\text { Oct } 4 \\
\text { Mean fold } \\
\text { expression }\end{array}$} & \multirow[t]{2}{*}{ Pvalue } & \multicolumn{2}{|c|}{$\begin{array}{c}\text { Cyclin } \\
\text { D1Exp. }\end{array}$} & \multirow{2}{*}{$\begin{array}{l}\text { Cyclin D1 } \\
\text { Mean fold } \\
\text { expression }\end{array}$} & \multirow[t]{2}{*}{ P value } & \multicolumn{2}{|c|}{ Survinin Exp. } & \multirow{2}{*}{$\begin{array}{c}\text { Survinin } \\
\text { Mean fold } \\
\text { expression }\end{array}$} & \multirow[t]{2}{*}{ P value } \\
\hline & High & Low & & & High & Low & & & High & Low & & \\
\hline $\begin{array}{c}\text { Age }(\mathbf{y r}): \\
<50(n=22) \\
\geq 50(n=28)\end{array}$ & $\begin{array}{l}8 \\
7\end{array}$ & $\begin{array}{l}14 \\
21\end{array}$ & $\begin{array}{c}1.25 \pm 1.2 \\
1.07 \pm 1.27\end{array}$ & 0.65 & $\begin{array}{l}16 \\
21\end{array}$ & $\begin{array}{l}6 \\
7\end{array}$ & $\begin{array}{l}2.96 \pm 1.95 \\
2.76 \pm 1.67\end{array}$ & 0.66 & $\begin{array}{l}16 \\
16\end{array}$ & $\begin{array}{c}6 \\
12\end{array}$ & $\begin{array}{c}2.97 \pm 1.74 \\
1.09 \pm 1.2\end{array}$ & 0.03 \\
\hline $\begin{array}{c}\text { Menopause: } \\
\text { Pre }(n=23) \\
\text { Post }(n=27) \\
\end{array}$ & $\begin{array}{l}8 \\
7 \\
\end{array}$ & $\begin{array}{l}15 \\
20 \\
\end{array}$ & $\begin{array}{l}1.22 \pm 1.2 \\
1.09 \pm 1.2 \\
\end{array}$ & 0.70 & $\begin{array}{l}17 \\
20 \\
\end{array}$ & $\begin{array}{l}6 \\
7 \\
\end{array}$ & $\begin{array}{l}2.86 \pm 1.8 \\
2.83 \pm 1.7 \\
\end{array}$ & 0.75 & $\begin{array}{l}15 \\
17 \\
\end{array}$ & $\begin{array}{c}8 \\
10 \\
\end{array}$ & $\begin{array}{c}2.7 \pm 1.8 \\
4.0 \pm 0.58\end{array}$ & 0.61 \\
\hline $\begin{array}{c}\text { Family History } \\
\text { Absent }(n=40) \\
\text { Present }(n=10)\end{array}$ & $\begin{array}{c}11 \\
4\end{array}$ & $\begin{array}{c}29 \\
6\end{array}$ & $\begin{array}{l}1.08 \pm 1.16 \\
1.44 \pm 1.52\end{array}$ & 0.05 & $\begin{array}{c}11 \\
8\end{array}$ & $\begin{array}{c}29 \\
2\end{array}$ & $\begin{array}{l}2.78 \pm 1.80 \\
3.14 \pm 1.77\end{array}$ & 0.83 & $\begin{array}{c}27 \\
5\end{array}$ & $\begin{array}{c}13 \\
5\end{array}$ & $\begin{array}{c}2.7 \pm 1.7 \\
2.28 \pm 2.17\end{array}$ & 0.03 \\
\hline $\begin{array}{c}\text { Tumor size (cm) } \\
\leq 5(\mathrm{n}=25) \\
>5(\mathrm{n}=25)\end{array}$ & $\begin{array}{c}10 \\
5 \\
\end{array}$ & $\begin{array}{l}15 \\
20 \\
\end{array}$ & $\begin{array}{l}0.46 \pm 0.17 \\
0.32 \pm 0.20 \\
\end{array}$ & 0.002 & $\begin{array}{l}19 \\
18 \\
\end{array}$ & $\begin{array}{l}6 \\
7 \\
\end{array}$ & $\begin{array}{c}0.344 \pm 0.18 \\
0.29 \pm 0.11\end{array}$ & 0.05 & $\begin{array}{l}25 \\
17 \\
\end{array}$ & $\begin{array}{c}10 \\
8 \\
\end{array}$ & $\begin{array}{l}2.49 \pm 1.8 \\
2.82 \pm 1.8 \\
\end{array}$ & 0.04 \\
\hline $\begin{array}{c}\text { Tumor stage } \\
\text { Early }(\mathrm{n}=29) \\
\text { Late }(\mathrm{n}=21)\end{array}$ & $\begin{array}{l}23 \\
14\end{array}$ & $\begin{array}{l}6 \\
7\end{array}$ & $\begin{array}{l}3.0 \pm 1.78 \\
2.64 \pm 1.8\end{array}$ & 0.03 & $\begin{array}{l}23 \\
14\end{array}$ & $\begin{array}{l}6 \\
7\end{array}$ & $\begin{array}{c}3.0 \pm 1.7 \\
2.64 \pm 1.8\end{array}$ & 0.06 & $\begin{array}{l}20 \\
12\end{array}$ & $\begin{array}{l}9 \\
9\end{array}$ & $\begin{array}{c}2.8 \pm 1.7 \\
2.45 \pm 1.9\end{array}$ & 0.002 \\
\hline $\begin{array}{c}\text { Tumor Grade } \\
\text { I-II }(\mathrm{n}=45) \\
\text { III }(\mathrm{n}=5)\end{array}$ & $\begin{array}{c}12 \\
3\end{array}$ & $\begin{array}{c}33 \\
2\end{array}$ & $\begin{array}{c}1.09 \pm 1.21 \\
1.81 \pm 1.3\end{array}$ & 0.003 & $\begin{array}{c}32 \\
3\end{array}$ & $\begin{array}{c}13 \\
2\end{array}$ & $\begin{array}{l}2.72 \pm 1.8 \\
3.98 \pm 1.1\end{array}$ & 0.02 & $\begin{array}{c}29 \\
3\end{array}$ & $\begin{array}{c}16 \\
2\end{array}$ & $\begin{array}{c}2.69 \pm 1.84 \\
2.31 \pm 2.0\end{array}$ & 0.04 \\
\hline $\begin{array}{c}\text { LN status: } \\
\text { Negative }(n=20) \\
\text { Positive }(n=30)\end{array}$ & $\begin{array}{l}6 \\
9\end{array}$ & $\begin{array}{l}14 \\
21\end{array}$ & $\begin{array}{l}1.12 \pm 1.14 \\
1.17 \pm 1.30\end{array}$ & 0.91 & $\begin{array}{l}12 \\
25\end{array}$ & $\begin{array}{l}8 \\
5\end{array}$ & $\begin{array}{l}2.29 \pm 1.81 \\
3.21 \pm 1.69\end{array}$ & 0.002 & $\begin{array}{l}10 \\
22\end{array}$ & $\begin{array}{c}10 \\
8\end{array}$ & $\begin{array}{c}2.20 \pm 1.99 \\
2.96 \pm 1.7\end{array}$ & 0.03 \\
\hline $\begin{array}{c}\text { Metastasis: } \\
\text { M0 }(n=40) \\
M 1(n=10)\end{array}$ & $\begin{array}{c}11 \\
4\end{array}$ & $\begin{array}{c}29 \\
6\end{array}$ & $\begin{array}{l}1.08 \pm 1.19 \\
1.42 \pm 1.40\end{array}$ & 0.02 & $\begin{array}{c}29 \\
8\end{array}$ & $\begin{array}{c}11 \\
2\end{array}$ & $\begin{array}{l}2.83 \pm 1.87 \\
2.91 \pm 1.44\end{array}$ & 0.32 & $\begin{array}{c}26 \\
6\end{array}$ & $\begin{array}{c}14 \\
4\end{array}$ & $\begin{array}{l}2.66 \pm 1.71 \\
2.65 \pm 2.12\end{array}$ & 0.33 \\
\hline
\end{tabular}




\section{Survival analysis.}

The average follow-up period was 43 months. The median overall survival of the 100 breast cancer patients was 43 months (range, 2-68 months), and the median time of disease-free interval was 42 months (range, 6-43 months). The triple negative breast cancer patients showed significantly decreased disease-free interval (DFS) $(\mathrm{p}<0.001, \log$ rank) and overall survival (OS) $(\mathrm{p}=0.002$, log rank) when compared to those with non-TNBC patients (Figure 1). In TNBC group, patients with positive expression of survivin was significantly associated with decreased OS ( $\mathrm{p}=0.03, \log$ rank).

On the other hand, TNBC tumors with positive oct4 and cyclin D1 had reduced OS compared to those negative to oct 4 and cyclin Dl but without significant difference $(\mathrm{p}=0.8$ and $\mathrm{p}=0.09$, respectively, log rank) (Figure 2). However, in non-TNBC group, with positive oct4, cyclin DI and survivin did not significantly differ in terms of DFS and OS when compared to those with negative expression (Figure 3).
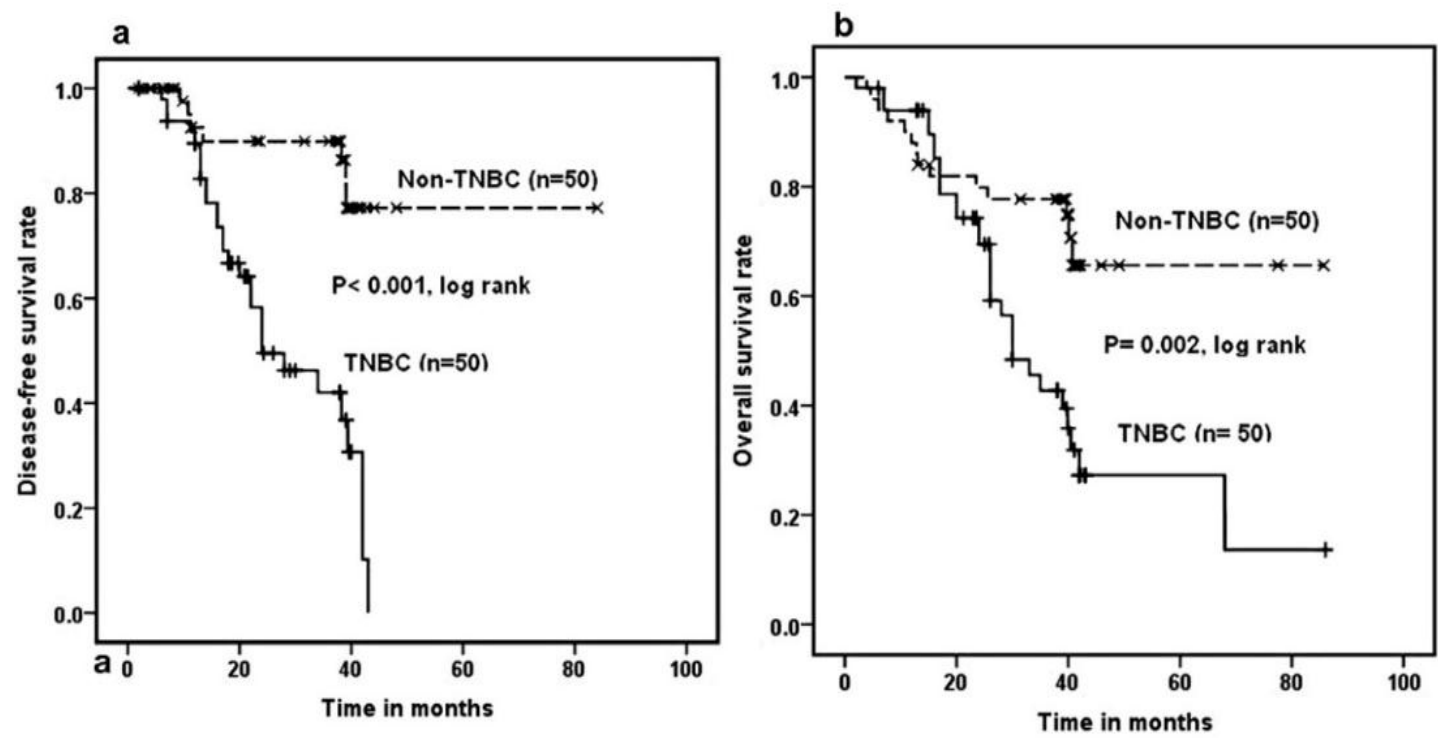

Figure 1: The disease-free survival and overall survival in TNBC and non-TNBC patients. 

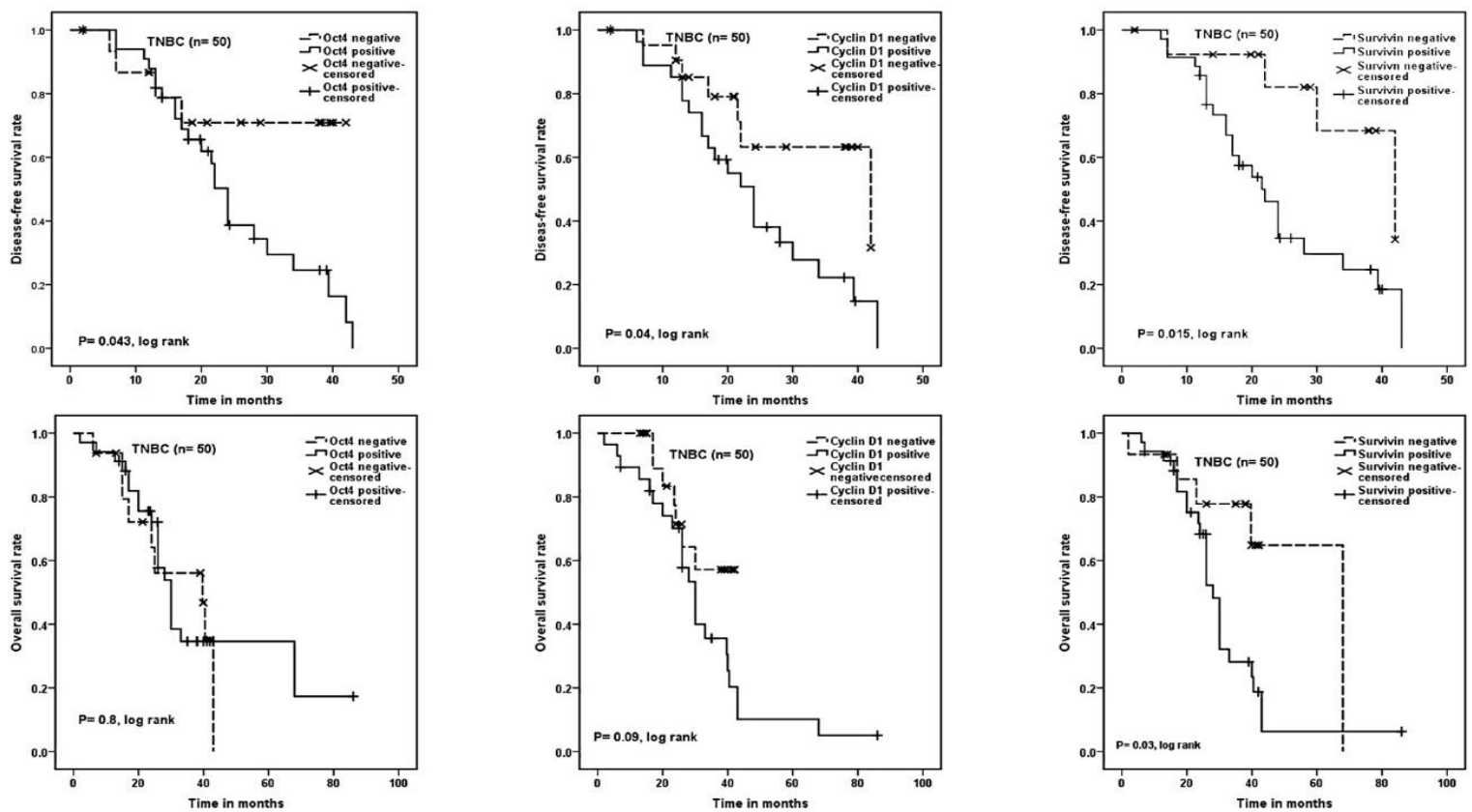

Figure 2: The gene expression in association to disease free survival and overall survival in TNBC patients.
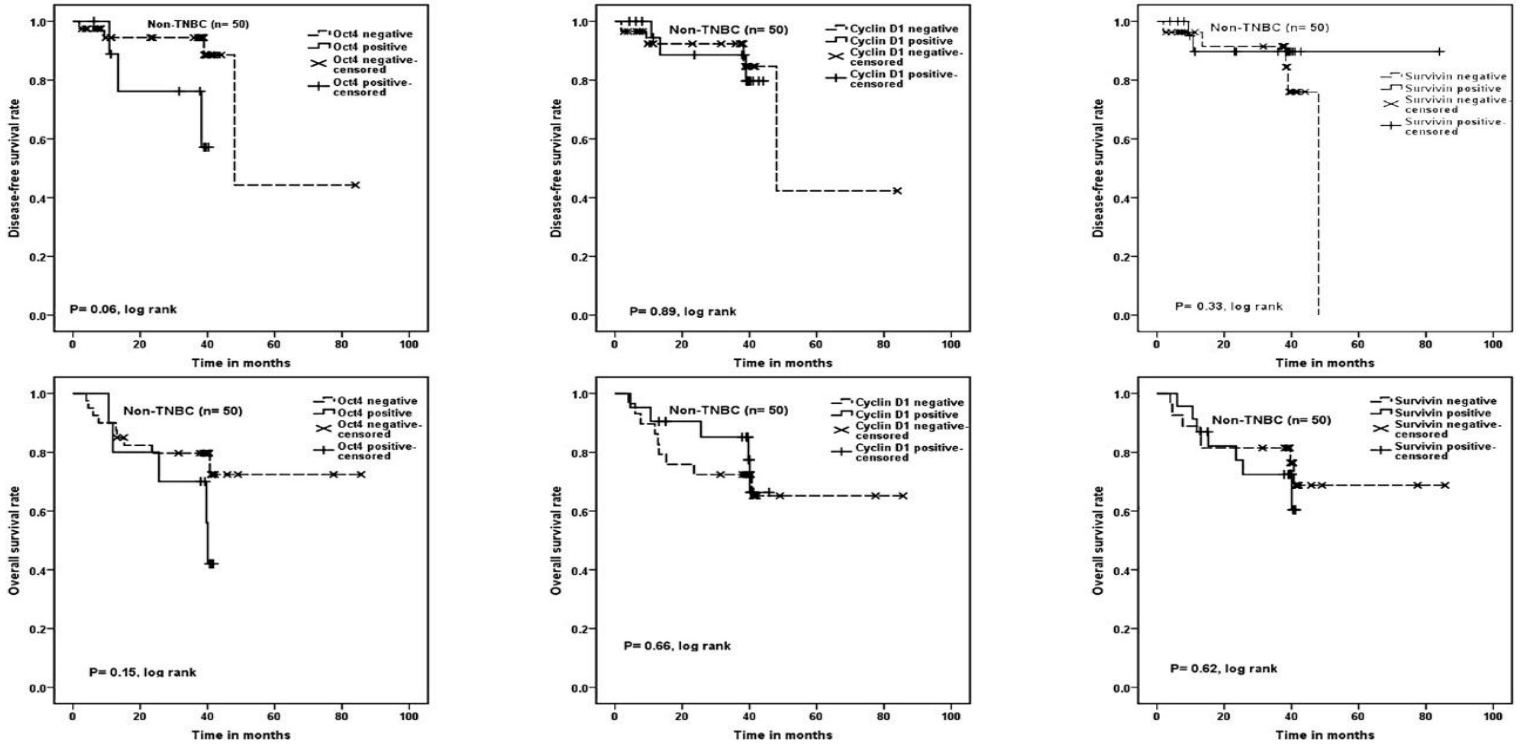

Figure 3: The gene expression in association to disease free survival and overall survival in non-TNBC patients 


\section{DISCUSSION}

Breast cancer is the most common type of cancer in women worldwide, represents $32 \%$ of the diagnostic cases in female and considered the second cause of cancer related death Houssami, N. and Cho, N. (2018).

Triple-negative breast cancer (TNBC) accounts for $12-17 \%$ of breast cancer cases and it is considered a discrete breast cancer subgroup. However, TNBC had been shown to constitute a vastly heterogeneous disease encompassing a wide spectrum of entities with marked genetic, transcriptional, histological type and clinical differences. Although most TNBCs are high-grade tumors, there are well-characterized group with low-grade tumors that usually have an indolent clinical course, better natural history; and molecular features as well as optimal the response to therapy vastly differ from those of high-grade TNBC Fresia Pareja et al., (2016).

In the current study, one-hundred tested patients were classified according to their age to two groups: 46 less than 50 years and 54 more than 50 years old. Twenty-two out 46 patients $(47.8 \%)$ which less than 50 years have NTBC and 24 out of them $(52.2 \%)$ with non-TNBC. Regarding to 54 patients with age more than 50 years, 28 of them $(51.9 \%)$ have TNBC and 26 out of them (48.1\%) with non-TNBC. No significant difference was reported between the two groups regarding to the age. This could be attributed to the small number of the patients assessed in the study.

In a previous study from Iran, the authors reported that 30 out of 214 patients (14\%) were TNBC and 184 (86\%) patients were non-TNBC. A significant difference was reported in this study where the mean age $( \pm \mathrm{SD})$ of the TNBC patients was $43( \pm 12)$ years whereas in the non-TNBC, the mean age of the patients was $50( \pm 12)$ years $(p=0.03)$. This study declared that TNBC is correlated with young age and therefore it is more aggressive Abdollahi, A. and Etemadi, M., (2016). Similarly, another study form Taiwan, reported a highly significant difference in the age of the patients between TNBC and non-TNBC groups Yao-Lung, K. et al., (2011). In another study by Li et al., (2013) they reported the statistically significant difference between the mean age of younger patients with TNBC group (49 years) compared to 54 years in nonon-TNBC group cases $(\mathrm{p}<0.003) \mathbf{L i}$, D. et al., (2017a). The discrepancy between results of the present study and previously reported ones may be due to the difference in genetic background and environmental factors. The epidemiological approaches may have also contributed to this discrepancy.

As for tumor size, $23(47.9 \%)$ out of the 48 cases were $\leq 5 \mathrm{~cm}$ in the non-TNBC patients compared to $25(52.1 \%)$ in the TNBC ones. As for, in patients with tumor size $>5 \mathrm{~cm} \mathrm{27/52} \mathrm{(51.9 \% )} \mathrm{cases} \mathrm{were} \mathrm{non-TNBC} \mathrm{and} \mathrm{25/52(48.1 \% )} \mathrm{were} \mathrm{TNBC}(\mathrm{p}=0.69)$. The results reported by Yao-Lung et al.(2011) and Abdollahi \& Etemadi (2016) agree with the current results. They found that there were no significant differences between the tumor size in the two groups. The mean size of the tumor was greater in TNBC than in non-TNBC group. The mean size in TNBC was3.83 $\pm 1.88(1-10 \mathrm{~cm}$ range $)$ and was $2.98 \pm 2.22$ in 
non-TNBC group (0.2-13 cm range). Similarly, Li et al. (2013) found the statistical difference between tumor size and the two groups $(\mathrm{p}=0.000)$. The TNBC patients had a bigger tumor more than the non-TNBC cases Li, D. et al., (2017a).

In the current study, three patients were with tumor grade I, two of them $(66.7 \%)$ from TNBC group and only one (33.3\%) from non-TNBC patients. Seventy-eight patients had the tumor grade II, $43(55.1 \%)$ were with TNBC compared to 35/78 (44.9\%) with non-TNBC. Finally, grade III was found in 19 cases, 5 of them 5/19 (26.3\%) were TNBC patients and $14(73.7 \%)$ in non-TNBC ones $(\mathrm{p}=0.12)$. In contrary to current data, studies by Abdollahi and Etemadi (2016), Yao-Lung et al.(2011) and Li et al.(2013) showed that grade III was significantly in TNBC and non-TNBC group $(p=0.02, p=0.0001$, $\mathrm{p}=0.008$ and $\mathrm{p}=0.00$; respectively). Yao-Lung et al. (2011) reported that the TNBC patients were with grade III (74 of 152, 48.7\%) $(\mathrm{p}=0.0001)$. In TNBC group, majority $35(56.4 \%)$ patients had modified Scarff Bloom-Richardson grade III tumors, whereas $24(38.7 \%)$ had grade II and $3(4.8 \%)$ had grade I tumors. In non-TNBC group, $22(18.6 \%)$ patients had grade I tumors, 53 (44.9\%) had grade II and 43 (36.4\%) had grade III tumors. The Chi-square test showed a significant difference in the distribution of histologic grade of the diagnosed TNBC and non-TNBC patients $(\mathrm{P}=0.008)$. Li et al. (2013) compared the histologic grade of TNBC and non-TNBC patients. In TNBC cases, there were 618 $(23.33 \%)$ with grade 1 tumors, $1118(42.20 \%)$ with grade 2 tumors and $913(34.47 \%)$ with grade 3 tumors. In non-TNBC cases, there were $4154(21.75 \%)$ Grade 1 tumor, 8721 (45.66\%) Grade 2 tumors and 6225 (32.59\%) Grade 3 tumors. The Chi-square test showed a significant difference in the distribution of histologic grade of the diagnosed TNBC and non-TNBC $(\mathrm{P}=0.001)$.

According to tumor stages, early stage was significantly more common in the TNBC group compared to the non-TNBC groups. Tumor stage I was recorded in 21 cases [21(100\%) was in TNBC). The patients which had tumor stage II were in 59 patients [29(49.2\%) in TNBC versus 30(50.8\%)]. As for late stage III and IV, all $20(100 \%)$ patients with non-TNBC tumor compared to $0 / 20(0 \%)$ were in TNBC patients. Stage (III) was detected more frequently in the TNBC compared to non-TNBC where stage (III-IV) was more significant in non-TNBC than those in TNBC. Nabi, et al. (2015), they study the clinicopathological features of 180 cases of TNBC and non-TNBC tumors, 5(8.0\%) cases at stage I, $28(45.1 \%)$ cases at stage II and III, 1 (1.6\%) case at stage IV in TNBC tumor. In non-TNBC group, $22(18.6 \%)$ cases were diagnosed with disease at stage I, $52(44.0 \%)$ cases at stage II, $42(35.5 \%)$ cases at stage III and $2(1.6 \%)$ cases at stage IV. Li et al. (2013), they reported that no significant association between tumor stage and TNBC or non-TNBC. The results of the previous studies were contrary with current data.

The lymph nodes were positive in $43(58.9 \%)$ out of the 73 patients in the TNBC group compared to $30(41.1 \%)$ patients in the non-TNBC. lymph nodes were negative in $7(25.9 \%)$ TNBC patients and $20(74.1 \%)$ non-TNBC $(\mathrm{p}=0.003)$. Surgical margins of the lumens were positive in 7 patients, all of them $(100 \%)$ were TNBC patients compared to none in the non-TNBC group. The study of Nabi et al. (2015) included 180 breast cancer patients, 62 out of them $(34.4 \%)$ were NBC patients. They reported that the lymphovascular 
involvement and axillary lymph node metastasis was more in TNBC group than those in non-TNBC group. Also, the extra nodal spread increased in non-TNBC cases than in TNBC patients. No statistically insignificant were recorded between the lymph node status and the two group $(p=0.246)$. Yao-Lung et al. (2011) found that the lymph node not significant between TNBC and non-TNBC group $(\mathrm{p}=0.307)$. These results are on the contrary with the current results, there was a significant association between the lymph node status in the two groups, whereas $43(58.9 \%)$ out of the 73 patients with positive in the TNBC compared to only $30(41.1 \%$ ) cases in non-TNBC. Also, the negative lymph node was detected in $7(25.9 \%)$ TNBC patients compared to $20(74.1 \%)$ non-TNBC patients (p=0.003) Yao-Lung et al.(2011). However, our data agree with Li et al. (2013), they compared the positive and negative lymph node in TNBC and non-TNBC patients. The number of lymph node was high in TNBC $(71.39 \%)$ patients than those of non-TNBC (36.78\%) patients. A significant difference was found between positive lymph node in the two groups $(\mathbf{p}=\mathbf{0 . 0 0 0})$ Li et al.(2013b).

In the current study, as for the presence of family history, a higher proportion of patients had positive family history in the TNBC group. Patients thar have a family history were eleven; 10 of them $(90.9 \%)$ in TNBC group and only one $(9.1 \%)$ in nonTNBC ( $\mathrm{p}=0.05)$. A study by Li et al. (2013) which was carried out on 21,749 breast cancer patients, declared that TNBC which is related to family history of breast cancer may be increased metastatic risk and have a poor prognosis. They found that family history was in one member for 4227 cases, two members for 1607 cases and 3 or more members for 444 cases members had breast cancer family members in non-TNBC patients. A significantly propagation of breast cancer reported with the members who had family history in TNBC cases compared to non-TNBC cases $(p=0.000)$ Li et al.(2013b).

According to the response to treatment, Yin et al. (2009) recorded that $87.30 \%$ of TNBC patients respond to treatment compared to $13.70 \%$ not responders. In subgroups $(E R B B 2+$ and $H R+/ E R B B 2-), 88.33 \%$ and $85.61 \%$; respectively were responders and $11.67 \%$ and $14.39 \%$ did not respond to treatment; there was no statistically difference between respond to treatment between these two groups Yin et al. (2009). This result is corresponded with the present data, where in fifty-five tested patients were responders to treatment, 35 out of $55(63.6 \%)$ were non-TNBC patients and 20 of them (36.4\%) were TNBC patients. Out of 45 non-responder patients, 33 (73.3\%) in TNBC patients and 12 $(26.7 \%)$ in non-TNBC patients.

In the current study, the RNA expression levels of oct4, cyclin D1 and survivin genes in all studied patients were $39(78 \%), 33(66 \%)$ and $35(70 \%)$; respectively in nonINBC tumor compared to $20(40 \%), 18(36 \%)$ and $18(36 \%)$; respectively in TNBC tumor. The data showed statistical significance in the distribution of the RNA expression level of all genes and the two groups $(p<0.001, p=0.003$ and $p=0.001$; respectively. Ezeh et al.,(2005) also found that normal breast tissues do not express detectable levels of oct 4 expression, and breast carcinoma in advanced stage reveals oct4 expression along with other stem cell markers Ezeh et al.,(2005). In addition, Chang et al.,2011) demonstrated that oct 4 promotes tumorigenesis of colorectal cancer cells in both autocrine and paracrine 
way. Saigusa et al., (2009) showed that oct4 expression is usually associated with the recurrence of rectal cancer after chemo-radiotherapy Saigusa et al., (2009) and Liu et al., (2014) reported that the oct 4 expression is positively correlated to breast cancer as it has a role in angiogenesis vasculogenic mimicry formation by increasing cancer stem cells subpopulation, thereby potentiating breast cancer metastasis Liu et al., (2014). Similarly, tumor tissue oct4 expression was positively correlated with histologic grade, pathological tumor size, $\mathrm{N}$ stage and TNM stage, and it could be served as an independent biomarker to predict worse prognosis in surgical patients with TNBC Zhang et al.(2018).

The median overall survival of the 100 breast cancer patients was 43 months (range 2 - 68 months), and the median time of disease-free interval was 42 months (range6 43 months). Triple negative breast cancer patients showed significantly decreased diseasefree interval $(\mathrm{p}<0.001, \log$ rank) and overall survival ( $\mathrm{p}=0.002, \log$ rank) when compared to those with non-TNBC patients. In TNBC group, patients with positive expression of survivin were significantly associated with decreased OS in TNBC patients. On the other hand, TNBC tumors with positive oct4 and cyclin DI had reduced OS compared to those negative to oct 4 and cyclin Dl but without significant difference. However, in non-TNBC group with positive oct4, cyclin Dl and surviving, there was not significantly difference in terms of DFS and OS when compared to those with negative expression. These results showed decreased OS among TNBC patients compared to non-TNBC patients.

Goncalves et al., (2018), recorded that OS and DFS rates in 5-year were $62.1 \%$ and $57.5 \%$ for TNBC and $80.8 \%$ and $75.3 \%$ for non-TNBC, respectively $(P<.001)$. There was significantly increased OS and DFS among non-TNBC compared to TNBC patients.

Hernandez-Aya et al., (2011) showed that in a large cohort of TNBC patients, the median age of TNBC patients was 48 years (range, 21 - 87 years). The median follow-up of 53 months (range, 0.7 - 317 months). The 5-year follow-up of patients, OS or relapse free survival (RFS) rates was decreased significant with the number of positive lymph-node ( $<<$ .0001 ; each).

Qiu, J. et al., (2016), they reported that there were $38 \%$ of TNBC patients were died at 5-year follow up and $19 \%$ of non-TNBC cases. Regarding to recurrences, $43 \%$ were in TNBC patients versus $25 \%$ were in non-TNBC patients. In this study the recurrence rate was high than those in Chinese cohort (2016).

Che Lin, et al., (2009), they found that OS was poor in TNBC cases, otherwise, there was not significant difference between DFS and non-TNBC in a Taiwan cohort study

In conclusion: Oct4 gene expression is significantly correlated with clinicpathological features of patients. Survivin gene is useful prognostic marker in TNBC and might be useful for molecular targeting therapy of TNBC treatment. Cyclin D1 may acts as a marker for the aggressive TNBC. These tumors may respond to target therapy that downregulates cyclin D1 amplification. More research with large samples size is needed. 


\section{REFERENCES}

Abdollahi, A. and Etemadi, M., 2016. Pathological Characteristics of Triple-Negative Breast Cancer at Main Referral Teaching Hospital, April 2014 to April 2015, Tehran, Iran. Int J Hematol Oncol Stem Cell Res 10, 200-205.

Boullosa, L.F., Savaliya, P., Bonney, S., Orchard, L., Wickenden, H., Lee, C., Smits, E., Banham, A.H., Mills, K.I., Orchard, K. and Guinn, B.A., 2018. Identification of survivin as a promising target for the immunotherapy of adult Bcell acute lymphoblastic leukemia. Oncotarget 9, 3853-3866.

Chang CJ, Chien Y, Lu KH, Chang SC, Chou YC, Huang CS, Chang CH, Chen KH, Chang YL, Tseng LM et al., 2011. Oct4-related cytokine effects regulate tumorigenic properties of colorectal cancer cells. Biochem Biophys Res Commun 415(2):245-251.

Che Lin, Su-Yu Chien, Li-Sheng Chen, Shou-Jen Kuo, Tsai-Wang Chang and DarRen Chen.2009. Triple negative breast carcinoma is a prognostic factor in Taiwanese women.BMC Cancer 2009, 9:192

Choi, E.K., Lim, J.A., Kim, J.K., Jang, M.S., Kim, S.E., Baek, H.J., Park, E.J., Kim, T.H., Deng, C.X., Wang, R.H. and Kim, S.S., 2018. Cyclin B1 stability is increased by interaction with BRCA1, and its overexpression suppresses the progression of BRCA1-associated mammary tumors. Exp Mol Med 50, 136.

Curtis C, Shah SP, Chin SF, Turashvili G, Rueda OM, Dunning MJ, Speed D,Lynch AG, Samarajiwa S, Yuan Y, et al. 2012. The genomic and transcriptomic architecture of 2,000 breast tumours reveals novel subgroups. Nature. 486(7403):346-52.).

Danielle Bogan, Lucio Meile, Ahmed El Bastawisy, Hend F. Yousef, Abdel-Rahman N. Zekri, Abeer A. Bahnassy and Wael M. EIShamy.2017. The role of BRCA1IRIS in the development and progression of triple negative breast cancers in Egypt: possible link to disease early lesion. BMC Cancer.17:329.

El-Hawary, A.K., Abbas, A.S., Elsayed, A.A., and Zalata, K.R. 2012. Molecular subtypes of breast carcinoma in Egyptian women: clinicopathological features. Pathol Res Pract 208 (7), 382-386.

Ezeh, U.I., Turek, P.J., Reijo, R.A. and Clark, A.T., 2005. Human embryonic stem cell genes OCT4, NANOG, STELLAR, and GDF3 are expressed in both seminoma and breast carcinoma. Cancer 104, 2255-2265. 
Fletcher CDM BJ, Hogendoorn PCW, Mertens F. 2013. World Health Organization, classification of tumours: Pathology and genetics of tumors of soft tissue and bone. Lyon: IARC Press.

Fresia Pareja, Felipe C Geyer, Caterina Marchiò, Kathleen ABurke, Britta Weigelt and Jorge S Reis-Filho. 2016. Triple-negative breast cancer: the importance of molecular and histologic subtyping, and recognition of low-grade variants. Npj. Breast Cancer

Goncalves, H., Jr., Guerra, M.R., Duarte Cintra, J.R., Fayer, V.A., Brum, I.V. and Bustamante Teixeira, M.T., 2018. Survival Study of Triple-Negative and NonTriple-Negative Breast Cancer in a Brazilian Cohort. Clin Med Insights Oncol 12.

Hernandez-Aya, LF, Chavez-MacGregor, M, Lei, X. 2011.Nodal status and clinical outcomes in a large cohort of patients with triple-negative breast cancer. J Clin Oncol. 29:2628-2634.

Houssami, N. and Cho, N., 2018. Screening women with a personal history of breast cancer: overview of the evidence on breast imaging surveillance. Ultrasonography 37, 277-287.

Kaplan, H.G., Malmgren, J.A., and Atwood, M. 2009. T1N0 triple negative breast cancer: risk of recurrence and adjuvant chemotherapy. Breast J 15(5), 454-460.

Li, C.Y., Wang, P., Zhang, S., Liu, Y. and Zhang, J., 2013. [Clinicopathological features and prognosis of triple-negative breast cancer]. Zhonghua Zhong Liu Za Zhi 35, 463-467.

Li, C.Y., Zhang, S., Zhang, X.B., Wang, P., Hou, G.F. and Zhang, J., 2013 b. Clinicopathological and prognostic characteristics of triple- negative breast cancer (TNBC) in Chinese patients: a retrospective study. Asian Pac J Cancer Prev 14, 3779-3784.

Li, D., Mai, V., Gerke, T., Pinney, S.M. and Yaghjyan, L., 2017a. Interactions of Family History of Breast Cancer with Radiotherapy in Relation to the Risk of Breast Cancer Recurrence. J Breast Cancer 20, 333-339.

Li, P., Zhou, L., Zhao, T., Liu, X., Zhang, P., Liu, Y., Zheng, X. and Li, Q., 2017 b. Caspase-9: structure, mechanisms and clinical application. Oncotarget 8, 2399624008.

Liedtke, C., Mazouni, C., Hess, K.R., Andre, F., Tordai, A., Mejia, J.A., Symmans, W.F., Gonzalez-Angulo, A.M., Hennessy, B., Green, M., et al. 2008. Response 
to neoadjuvant therapy and long-term survival in patients with triple-negative breast cancer. J Clin Oncol 26(8), 1275-1281).

Liu, A., Yu, X. and Liu, S., 2013. Pluripotency transcription factors and cancer stem cells: small genes make a big difference. Chin J Cancer 32, 483-487.

Liu, T., Sun, B., Zhao, X., Li, Y., Gu, Q., Dong, X. and Liu, F., 2014. OCT4 expression and vasculogenic mimicry formation positively correlate with poor prognosis in human breast cancer. Int J Mol Sci 15, 19634-19649.

Malumbres, M. and Barbacid, M., 2005. Mammalian cyclin-dependent kinases. Trends Biochem Sci 30, 630-641.

Munjal, K., Ambaye, A., Evans, M.F., Mitchell, J., Nandedkar, S., and Cooper, K. 2009. Immunohistochemical analysis of ER, PR, Her2 and CK5/6 in infiltrative breast carcinomas in Indian patients. Asian Pac J Cancer Prev 10(5), 773-778.

Nabi, M.G., Ahangar, A., Wahid, M.A. and Kuchay, S., 2015. Clinicopathological comparison of triple negative breast cancers with non-triple negative breast cancers in a hospital in North India. Niger J Clin Pract 18, 381-386.

Qiu, J, Xue, X, Hu, C. 2016. Comparison of clinicopathological features and prognosis in triple-negative and non-triple negative breast cancer. J Cancer.7:167-173

Saigusa, S., Tanaka, K., Toiyama, Y., Yokoe, T., Okugawa, Y., Ioue, Y., Miki, C. and Kusunoki, M., 2009. Correlation of CD133, OCT4, and SOX2 in rectal cancer and their association with distant recurrence after chemoradiotherapy. Ann Surg Oncol 16, 3488-3498.

Sarosiek, T., 2018. [Inhibitors of cyclin-dependent kinases (CDK) - a new group of medicines in therapy of advanced breast cancer]. Pol Merkur Lekarski 44, 5-9.

Schmittgen TD and Livak KJ. 2008.Analyzing real-time PCR data by the comparative C(T) method. Nat Protoc. 3(6):1101-8.

Shen, L., Qin, K., Wang, D., Zhang, Y., Bai, N., Yang, S., Luo, Y., Xiang, R. and Tan, X., 2014. Overexpression of Oct4 suppresses the metastatic potential of breast cancer cells via Rnd1 downregulation. Biochimica et biophysica acta 1842, 2087-2095.

Weigelt, B., Baehner, F.L. and Reis-Filho, J.S., 2010a. The contribution of gene expression profiling to breast cancer classification, prognostication and prediction: a retrospective of the last decade. J Pathol 220, 263-280. 
Yao-Lung, K., Dar-Ren, C and Tsai-Wang, C., 2011. Clinicopathological features of triple-negative breast cancer in Taiwanese women. Int J Clin Oncol 16, 500-505.

Yin, W.J., Lu, J.S., Di, G.H., Lin, Y.P., Zhou, L.H., Liu, G.Y., Wu, J., Shen, K.W., Han, Q.X., Shen, Z.Z. and Shao, Z.M., 2009. Clinicopathological features of the triple-negative tumors in Chinese breast cancer patients. Breast Cancer Res Treat 115, 325-333.

Zhang, J.M., Wei, K. and Jiang, M., 2018. OCT4 but not SOX2 expression correlates with worse prognosis in surgical patients with triple-negative breast cancer.Breast Cancer 25, 447-455. 


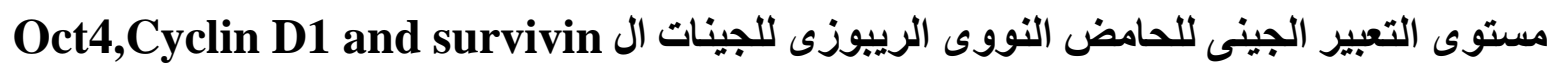
فى مرضى سرطان الثدى ثلاثى السلبية و غير ثلاثى السلبية النية

صفاء فوزي'* ، كريمة متولي' ، محمود الروبي' ، عبير بهنسيَ

'قسم الفيروسات و المناعة معهد الاورام القومي جامعة القاهرة ،مصر

آقسم طفيليات بكلية العلوم جامعة الاز هر ،القاهرة ،مصر

"قاتم باثولوجي جزيئية ،معهد الاورام ،جامعة القاهرة ،مصر

safaa.hafez.59@azhar.edu.eg : البريد الاكتروني للباحث الرئيسي:*

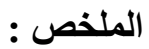

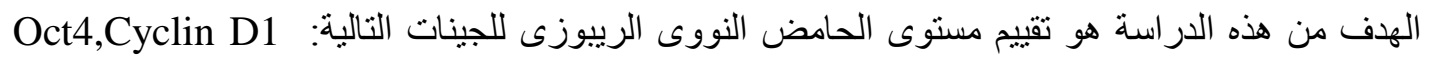

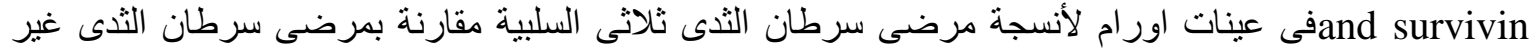

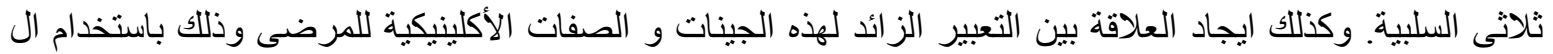

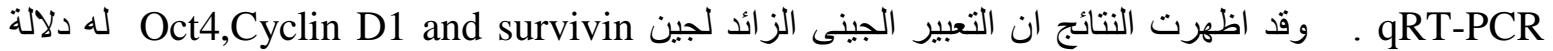
احصائية فى مجمو عة مرضى سرطان الثذى ثلاثى السلبية كما فى مجمو عة مرضى سرطان الثدى الغير ثناثى السلبية.

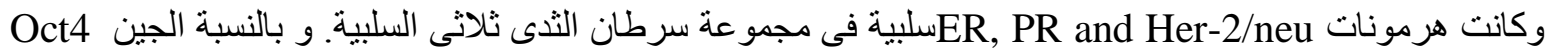

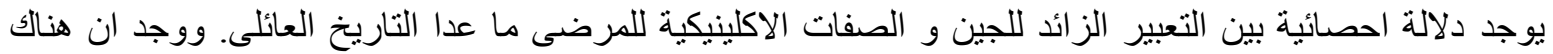

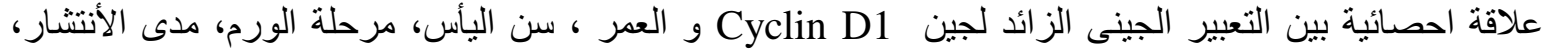

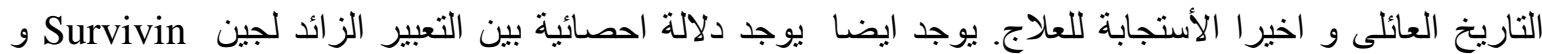

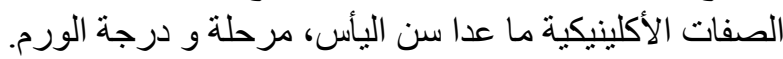

وجد ان مرضى سرطان الثذى ثلاثى السلبية له دلالة احصائية تقلل من (DFS) وهى فترة بقاء المريض على الثى

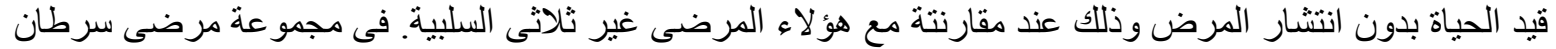

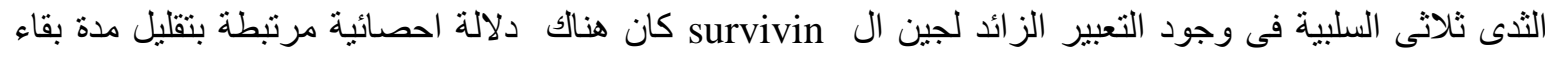

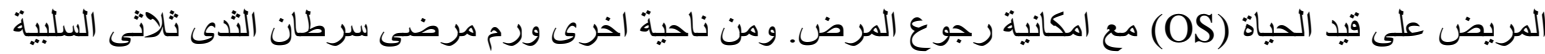

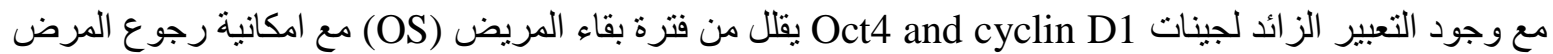

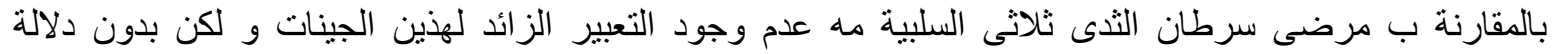

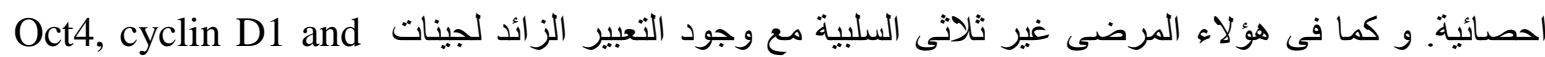

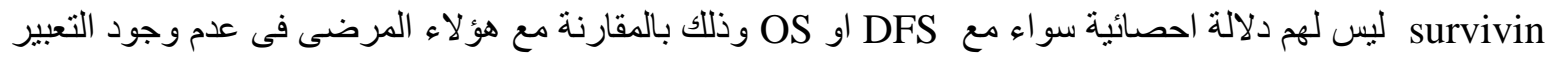

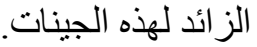

و من هذه الدراسة نجد ان تقييم التعبير الزائد للثلاث جينات قد يكون عامل مؤثر فى التشخيص والعلاج لمرضى سرطان الثدى ثلاثى السلبية. الكلمات المفتاحية :- سرطان الثذي ثلاثي السلبية ، سرطان الثذي الغير ثلاثي السلبية، جين الاكتوفور، جين السيكلين، جين السرفيفين 